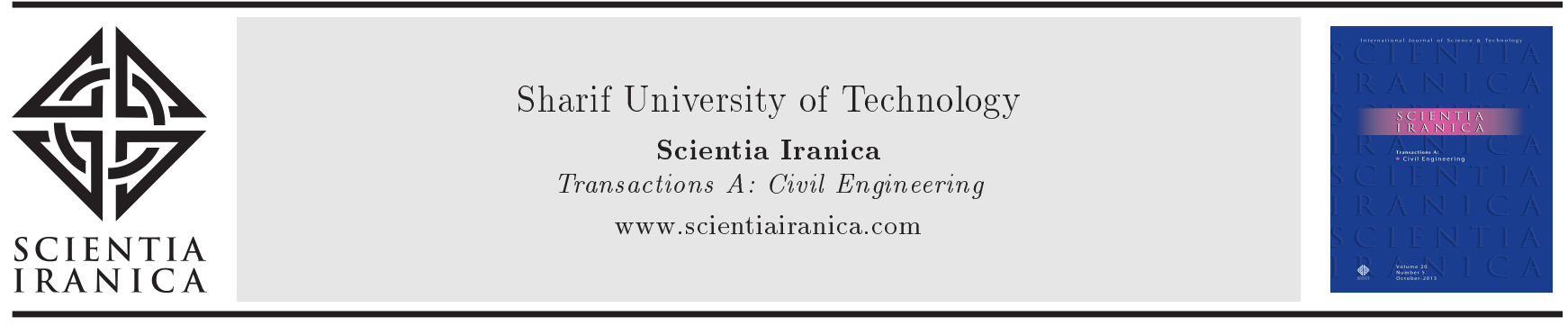

\title{
Determination of the pollution control flow for drought management in a multi-reservoir system
}

\author{
M. Opan* \\ Department of Civil Engineering, Engineering Faculty, Kocaeli University, Kocaeli, Turkey.
}

Received 18 March 2015; received in revised form 18 August 2015; accepted 12 October 2015

\author{
KEYWORDS \\ Pollution control flow; \\ Correlation and \\ regression analyses; \\ Artificial neural \\ networks; \\ Drought management; \\ Multi-reservoir \\ system.
}

\begin{abstract}
The pollution, changing according to various standards, is directly proportional to water quality in rivers. In this study, data and restrictions prescribed for standards of water quality such as Turkish Standards Institute (TSI), European Commission (EC), and the World Health Organization (WHO) were used to determine water pollution. For this purpose, correlation analysis was made to identify strong relationships between data. Regression analysis and Artificial Neural Networks (ANN) models are developed based on these standards by data obtained from correlation analysis. The Lower Sakarya River is selected as application area, and measurement of the water quality values of this river is used in these models. Pollution control flows in the river are obtained by the ANN models and regression analysis. The obtained results are compared with regard to these standards.
\end{abstract}

(C) 2016 Sharif University of Technology. All rights reserved.

\section{Introduction}

Inflow released from reservoir to the river for drought management in a multi-reservoir system is expected to be on the pollution control flows in the rivers. Therefore, the pollution control flow of the river presented between reservoirs in the system should be determined. Plus, pollution value in the river depends on factors such as the water quality and the properties of the river bed, and it contains data and constraints presented by standards such as TSI, EC, and WHO. In these standards, generally, constraints present in the amounts of substances, which negatively affect the water quality, have been investigated.

Water pollution discharges substances and energy waste into the biological source, human health, fishing life, and the water quality and causes inhibitive corruptions and the chemical, physical, bakteriological, radioactie and ecological properties of the water source

*. Tel: +90 262 3033272

E-mail address: opanmucahit@yahoo.com can be observed with changing as negatively in be used for other aims of water by direct or indirect ways.

Intense and unconscious usage of the pollution sources such as industrialization, urbanization, agricultural pesticides with population growth and chemical fertilizers are indicators of the causes of water pollution. For example, water resources have been contaminated as the result of drug granules thrown in the water, agricultural pesticide spray carried by wind over lands, and factory waste's discharge into the lakes and river. On the other hand, unconscious and excessive use of the chemical fertilizers causes soil infertility; therefore, both water pollution within natural circle of life and other adverse effects occur [1].

There have been some studies about the water pollution in rivers, reservoirs, and basins in the last decade [2-6]. For example, a water quality model for Zayandeh Rud river was developed. The main objective of the developed model was to create a simple river pollution model to be used for quick analysis of river water quality. The model focuses on ANN algorithm instead of usual river quality models which 
accounts for the physical processes of pollutant changes along the river [3]. Estimation of dissolved oxygen capacity for water quality control of Melen River in Tukey was investigated using ANN algorithm at each measurement point in the river by the limited data. The required data were collected and determined from experimental studies, and also correlation coefficient was obtained by ANN model [4]. A model for optimal pollution control for the Fei-Tsui Reservoir Basin in Northern Taiwan was developed [5]. The potential of ANN algorithm in the estimation of the Biological Oxygen Demand (BOD) of the Melen River in Turkey was examined by comparing the results with observed BOD. In addition, sensitivity analysis was conducted to determine the degree of effectiveness of the variables by various performance statistics [6].

Some studies about effects of drought on pollution were performed by artificial neural network [79]. Drought effects on river pollution with ANN were studied [8]. As a result, some pollution parameters were directly affected by usage of the integrated models for water management. Water quality for evaluating the evolution of pollutants in river systems was proposed during drought periods in diverse action measure scenarios, including water management and water quality measures [9].

Water and sediment samples were collected along the Lower Sakarya River Basin from pre-determined sampling stations between February 2007 and January 2008 monthly during 12 months of time. A total of 40 elements such as Vanadium, Chromium, and Manganese in water were analyzed by Inductively Coupled Plasma-Mass Spectrometer (ICP-MS). In addition, selected physical and chemical parameters of water and sediment samples were measured at the sampling point and/or laboratory. Effects of anthropogenic activities on the Lower Sakarya River were investigated. The impacts of dam, levels, and bridge constructions, sand-gravel mining activities, and water withdrawals during the industrialization period of the Sakarya River Basin were explored by analyzing flow, sediment, and channel cross section data from different periods in time along with comparing historical (preand post-1975) periods [10].

In this study, ANN models were developed to determine pollution control flow during drought management in a multi-reservoir system by correlation analysis and water quality values of standards such as TSI, EC, and WHO. The Lower Sakarya River was selected for application. Strong relationships between the measured water quality data and the observed flow rates of the river are determined by correlation analysis. The strong correlations in terms of impact data with each other were assigned as input data and as output data by ANN models and also by the regression analysis. As a result of these processes, the obtained

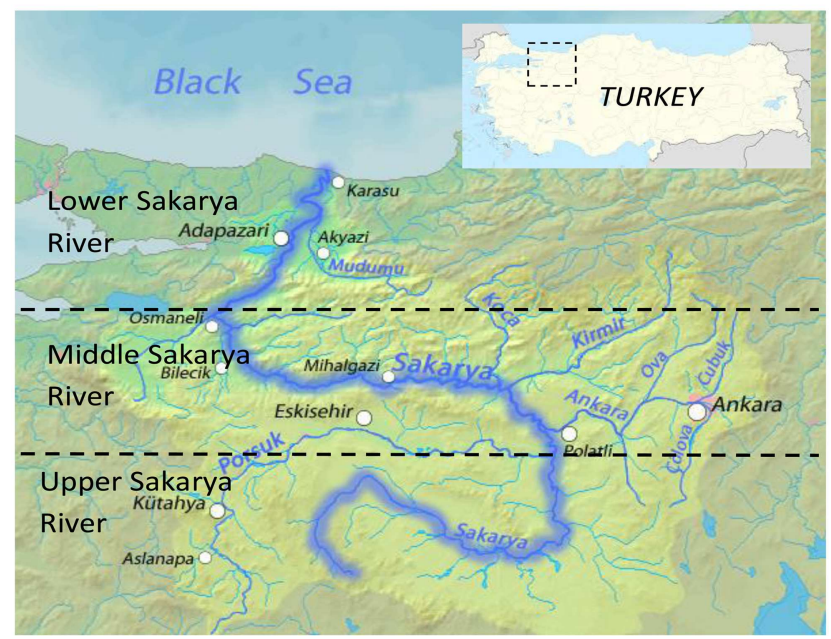

Figure 1. View of the Sakarya River Basin.

results from these models and regression analysis are compared with regard to these standards.

\section{Application area: The Sakarya River Basin}

The Sakarya River Basin, one of most important river basins in Turkey, as shown in Figure 1, is surrounded by basins of the Kizllırmak River, the Western Black Sea, Marmara, Susurluk, Gediz, Akarcay, and Konya. The Sakarya River Basin is commonly divided into three zones as upper, middle, and lower sections.

There are 20 dams built between years 1936 and 2002 for domestic and industrial water supply, irrigation, flood control, and energy purposes on a multireservoir system of the basin. The relatively larger dams, with their locations, rivers, types, purposes, and reservoir capacities are shown in Table 1.

When the basin is investigated, it is observed that industrial companies have densely been located in the Lower Sakarya River. Therefore, it can be said that there was water pollution in its region. When the region is investigated to measure water quality values and other flow data, it is observed that the sediment values for the water quality were measured, as given in Table 2, by the Scientific and Technological Research Council of Turkey and were prepared to report these data.

\section{Water quality standards}

The flow rate for pollution control produced by water quality standards may be used in the management of events, such as drought control of a multi-reservoir system. A country's economic conditions and living standards should be adapted to its location. Therefore, water quality standards of TSI, EC, and WHO were used in this study.

Water quality standards are arranged by taking 
Table 1. General characteristics of relatively large dams on the Sakarya River.

\begin{tabular}{|c|c|c|c|c|c|}
\hline Dams & Location & River & Type & Purpose & $\begin{array}{c}\text { Reservoir } \\
\text { capacity } \\
\left(\mathrm{hm}^{3}\right)\end{array}$ \\
\hline Çubuk I & Ankara & Çubuk & Concrete Gravity & $\begin{array}{l}\text { Domestic and industrial water supply, } \\
\text { Flood control }\end{array}$ & 12.50 \\
\hline Sarıyar & Sarıyar- Nallıhan & Sakarya & Concrete Gravity & Energy & 1900 \\
\hline Çubuk II & Ankara-Çubuk & Çubuk & Soil-filled & Domestic and industrial water supply & 24.60 \\
\hline Bayındır & Ankara & Bayındır & Soil-filled & Domestic and industrial water supply & 6.97 \\
\hline Kurtboğazı & Ankara & Kurtboğazı & Soil-filled & Domestic and industrial water supply & 101.50 \\
\hline Musaözü & Eskişehir & Mollaoğlu & Soil-filled & Irrigation & 1.67 \\
\hline Porsuk & Eskişehir & Porsuk & Concrete Gravity & $\begin{array}{l}\text { Domestic and industrial water supply, } \\
\text { Irrigation, Flood control }\end{array}$ & 431 \\
\hline Gökşekaya & Eskişehir & Sakarya & Concrete Arch & Energy & 910 \\
\hline Dodurga & Bilecik & Sarısu & Soil-filled & Irrigation, Flood control & 22 \\
\hline Kaymaz & Eskişehir & Çayırlık & Soil-filled & Irrigation & 1.43 \\
\hline Enne & Kütahya & Dereboğazı & Soil-filled & Domestic and industrial water supply & 7 \\
\hline Asartepe & Ankara & İlhan & Soil-filled & Irrigation & 20 \\
\hline Kunduzlar & Eskişehir & Yönek & Soil-filled & Irrigation & 22 \\
\hline Çamlıdere & Ankara & Bayındır & Rock-filled & Domestic and industrial water supply & 1226 \\
\hline Çatören & Eskişehir & Haramşi & Soil-filled & Irrigation & 47 \\
\hline Eğrekkaya & Ankara & Sey & Soil-filled & Domestic and industrial water supply & 113 \\
\hline Akyar & Ankara & Bulak & Soil-filled & Domestic and industrial water supply & 56 \\
\hline Yenice & Eskişehir & Sakarya & Soil-filled & Energy & 57.60 \\
\hline Beyköy & Eskişehir & Sakarya & Concrete & Energy & River power plant \\
\hline Kizildamlar & Bilecik & Sögüut & Rock-filled & Irrigation & 10.70 \\
\hline
\end{tabular}

Table 2. Sediment values for the water quality on the lower Sakarya River.

\begin{tabular}{|c|c|c|c|c|c|c|c|c|c|c|c|c|c|}
\hline \multirow{2}{*}{ Elements } & \multirow{2}{*}{$\mathrm{S}$} & \multicolumn{12}{|c|}{ Months (kg/day) } \\
\hline & & January & February & March & April & May & June & July & August & September & October & November & December \\
\hline Aluminum & $\mathrm{Al}$ & 0,4964 & 0,0595 & 0,1452 & 0,0431 & 0,0125 & 0,0506 & 0,0168 & 0,0207 & 0,0302 & 0,0898 & 0,1152 & 0,1249 \\
\hline Antimony & $\mathrm{Sb}$ & 0,0330 & 0,0549 & 0,0467 & 0,0148 & 0,0103 & 0,0103 & 0,0168 & 0,0081 & 0,0139 & 0,0301 & 0,0239 & 0,0418 \\
\hline Arsenic & As & 0,0270 & 0,0608 & 0,0348 & 0,0445 & 0,0176 & 0,0241 & 0,0453 & 0,0186 & 0,0274 & 0,0496 & 0,0371 & 0,0954 \\
\hline Copper & $\mathrm{Cu}$ & 0,0033 & 0,0055 & 0,0186 & 0,0359 & 0,0010 & 0,0024 & 0,0017 & 0,0054 & 0,0060 & 0,0030 & 0,0082 & 0,0042 \\
\hline Barium & $\mathrm{Ba}$ & 0,3448 & 0,6162 & 0,3810 & 0,3678 & 0,1696 & 0,1581 & 0,2520 & 0,1451 & 0,2269 & 0,3658 & 0,2677 & 0,4957 \\
\hline Beryllium & $\mathrm{Be}$ & 0,0007 & 0,0110 & 0,0009 & 0,0475 & 0,0319 & 0,0122 & 0,0170 & 0,0308 & 0,0270 & 0,0653 & 0,0325 & 0,0469 \\
\hline Boron & B & 0,9643 & 2,3737 & 21,7100 & 2,0525 & 0,7070 & 1,2023 & 1,5454 & 0,6013 & 0,7308 & 2,6191 & 1,1196 & 4,1540 \\
\hline Mercury & $\mathrm{Hg}$ & 0,0007 & 0,0011 & 0,0009 & 0,0004 & 0,0002 & 0,0002 & 0,0003 & 0,0002 & 0,0003 & 0,0006 & 0,0005 & 0,0008 \\
\hline Zinc & $\mathrm{Zn}$ & 0,0428 & 0,0737 & 0,0527 & 0,0367 & 0,0103 & 0,0103 & 0,0168 & 0,0081 & 0,0139 & 0,0313 & 0,0527 & 0,1684 \\
\hline Silver & $\mathrm{Ag}$ & 0,0007 & 0,0011 & 0,0009 & 0,0004 & 0,0003 & 0,0002 & 0,0003 & 0,0002 & 0,0003 & 0,0342 & 0,0024 & 0,0010 \\
\hline Iron & $\mathrm{Fe}$ & 1,4839 & 0,8214 & 0,5051 & 0,6616 & 0,3767 & 0,2679 & 0,5055 & 0,2873 & 0,3848 & 0,4805 & 0,4783 & 0,7949 \\
\hline Cadmium & $\mathrm{Cd}$ & 0,0007 & 0,0011 & 0,0009 & 0,0004 & 0,0003 & 0,0002 & 0,0003 & 0,0002 & 0,0003 & 0,0342 & 0,0024 & 0,0010 \\
\hline Chrome & $\mathrm{Cr}$ & 0,0068 & 0,0105 & 0,0093 & 0,0074 & 0,0021 & 0,0021 & 0,0034 & 0,0016 & 0,0029 & 0,0060 & 0,0052 & 0,0084 \\
\hline Lead & $\mathrm{Pb}$ & 0,0013 & 0,0012 & 0,0013 & 0,0061 & 0,0004 & 0,0023 & 0,0003 & 0,0005 & 0,0003 & 0,0054 & 0,0015 & 0,0020 \\
\hline Manganese & $\mathrm{Mn}$ & 0,3625 & 0,3436 & 0,0720 & 0,0977 & 0,0132 & 0,0316 & 0,0245 & 0,0510 & 0,0719 & 0,1032 & 0,1202 & 0,3638 \\
\hline Molybdenum & Mo & 0,0100 & 0,0228 & 0,0127 & 0,0192 & 0,0038 & 0,0092 & 0,0136 & 0,0052 & 0,0105 & 0,2260 & 0,0253 & 0,0328 \\
\hline Nickel & $\mathrm{Ni}$ & 0,0204 & 0,0266 & 0,0245 & 0,0286 & 0,0088 & 0,0128 & 0,0118 & 0,0071 & 0,0179 & 0,0189 & 0,0205 & 0,0414 \\
\hline Selenium & $\mathrm{Se}$ & 0,0330 & 0,0549 & 0,0093 & 0,0043 & 0,0021 & 0,0021 & 0,0034 & 0,0016 & 0,0028 & 0,0060 & 0,0048 & 0,0084 \\
\hline Sodium & $\mathrm{Na}$ & 247,52 & 398,09 & 15,98 & 306,95 & 179,12 & 176,92 & 236,64 & 141,63 & 231,94 & 353,99 & 232,33 & 609,77 \\
\hline Thallium & $\mathrm{Tl}$ & 0,0007 & 0,0011 & 0,0009 & 0,0442 & 0,0255 & 0,0247 & 0,0256 & 0,0138 & 0,0238 & 0,0581 & 0,0232 & 0,0796 \\
\hline Flow rate & Q & 76,50 & 127,00 & 108,00 & 48,70 & 23,80 & 23,80 & 38,80 & 18,70 & 32,10 & 69,60 & 55,30 & 96,70 \\
\hline
\end{tabular}


into consideration the organoleptic properties, the microbiological properties, the chemical properties, and the indicator features. In the chemical properties of the water quality standards, a number of elements are taken into consideration such as Antimony ( $\mathrm{Sb}$ ), Arsenic (As), Barium (Ba), Boron (B), Mercury (Hg), Zinc (Zn), Iron (Fe), Silver (Ag), Chrome (Cr), Manganese (Mn), Nickel (Ni), Selenium (Se), Aluminum $(\mathrm{Al})$, Gold $(\mathrm{Au})$, and Copper $(\mathrm{Cu})$, which are given in Table 3 .

\section{Correlation and regression analyses}

Pearson's product-moment correlation coefficients were used to determine the effects of flow rate of the water quality parameters. Correlation analysis was performed in order to determine relationships between twenty elements and flow rate. Results are given in Table 4. Effects of twelve water quality parameters (Antimony (Sb), Arsenic (As), Barium (Ba), Boron (B), Mercury $(\mathrm{Hg})$, Zinc ( $\mathrm{Zn})$, Iron (Fe), Silver (Ag), Chrome (Cr), Manganese (Mn), Nickel (Ni), and Selenium (Se)) on flow rate (Q) were determined by using correlation analysis. Flow rate was positively and very significantly correlated with Antimony (Sb), Barium (Ba), Mercury (Hg), Silver (Ag), Chrome (Cr), Manganese (Mn), Nickel (Ni), and Selenium (Se) at the 0.05 level (2-tailed).

Effects of eight water quality parameters (Antimony (Sb), Barium (Ba), Mercury ( $\mathrm{Hg}$ ), Silver (Ag), Chrome (Cr), Manganese (Mn), Nickel (Ni), and Selenium (Se)) on flow rate $(\mathrm{Q})$ were determined by regression analysis; regression equation relationships between eight water quality parameters and flow rate are obtained as follows:

$$
\begin{aligned}
Q= & 1.41-0.63 S b-0.242 \mathrm{Ba}-0.164 \mathrm{Hg} \\
& +0.037 \mathrm{Ag}-0.895 \mathrm{Cr}+0.025 \mathrm{Mn}+2.48 \mathrm{Ni} \\
& -0.166 \mathrm{Se} .
\end{aligned}
$$

\section{Artificial Neural Networks (ANN) models}

Each one of the proposed ANN models has modeling, training, and test stages. It includes the examination of data, definition of the parameters of cost prediction, and election of the network structure and rules. in this case, eight sediment elements (Antimony (Sb), Barium (Ba), Mercury (Hg), Silver (Ag), Chrome (Cr), Manganese (Mn), Nickel (Ni), and Selenium (Se)) as input data and flow rate (Q) as output data on ANN models have been taken into consideration.

The proposed ANN model has been designed to consist of an input layer of sixteen neurons regarding the eight input factors, and an output layer of neuron as the goal (Figure 2). Weights to layer 1 from input

\begin{tabular}{|c|c|c|c|}
\hline Standards & $\begin{array}{c}\text { Turkish } \\
\text { Standards } \\
\text { Institute } \\
\text { (TSI) }\end{array}$ & $\begin{array}{c}\text { European } \\
\text { Commission } \\
\text { (EC) }\end{array}$ & $\begin{array}{c}\text { The World } \\
\text { Health } \\
\text { Organization } \\
\text { (WHO) }\end{array}$ \\
\hline \multicolumn{4}{|c|}{ Elements $\left(\mathrm{mgL}^{-1}\right)$} \\
\hline Aluminum & 0,2 & 0,2 & 0,2 \\
\hline Gold & 0 & 0 & 0 \\
\hline Antimony & 0,005 & 0,005 & 0,02 \\
\hline Arsenic & 0,01 & 0,01 & 0,01 \\
\hline Copper & 2 & 2 & 2 \\
\hline Barium & 0 & 0 & 0,7 \\
\hline Beryllium & 0 & 0 & 0 \\
\hline Bismuth & 0 & 0 & 0 \\
\hline Boron & 1 & 1 & 0,5 \\
\hline Mercury & 0 & 0,001 & 0,001 \\
\hline Zinc & 0 & 0 & 0 \\
\hline Iron & 0,2 & 0,2 & 0,3 \\
\hline Gallium & 0 & 0 & 0 \\
\hline Germanium & 0 & 0 & 0 \\
\hline Silver & 0 & 0 & 0 \\
\hline Cadmium & 0,005 & 0,005 & 0,003 \\
\hline Tin & 0 & 0 & 0 \\
\hline Calcium & 0 & 0 & 0 \\
\hline Cobalt & 0 & 0 & 0 \\
\hline Chrome & 0,05 & 0,05 & 0,05 \\
\hline Lead & 0,01 & 0,01 & 0,01 \\
\hline Lithium & 0 & 0 & 0 \\
\hline Magnesium & 0 & 0 & 0 \\
\hline Manganese & 0,05 & 0,05 & 0,4 \\
\hline Molybdenum & 0 & 0 & 0,07 \\
\hline Nickel & 0,02 & 0,02 & 0,02 \\
\hline Platinum & 0 & 0 & 0 \\
\hline Potassium & 0 & 0 & 0 \\
\hline Rhodium & 0 & 0 & 0 \\
\hline Selenium & 0,01 & 0,01 & 0,01 \\
\hline Cesium & 0 & 0 & 0 \\
\hline Silicium & 0 & 0 & 0 \\
\hline Sodium & 200 & 200 & 200 \\
\hline Strontium & 0 & 0 & 0 \\
\hline Thallium & 0 & 0 & 0 \\
\hline Tantalum & 0 & 0 & 0 \\
\hline Titanium & 0 & 0 & 0 \\
\hline Thorium & 0 & 0 & 0 \\
\hline Tungsten & 0 & 0 & 0 \\
\hline Vanadium & 0 & 0 & 0 \\
\hline
\end{tabular}

Table 3. Values of the water quality standards such as TSE, EC, and WHO. 


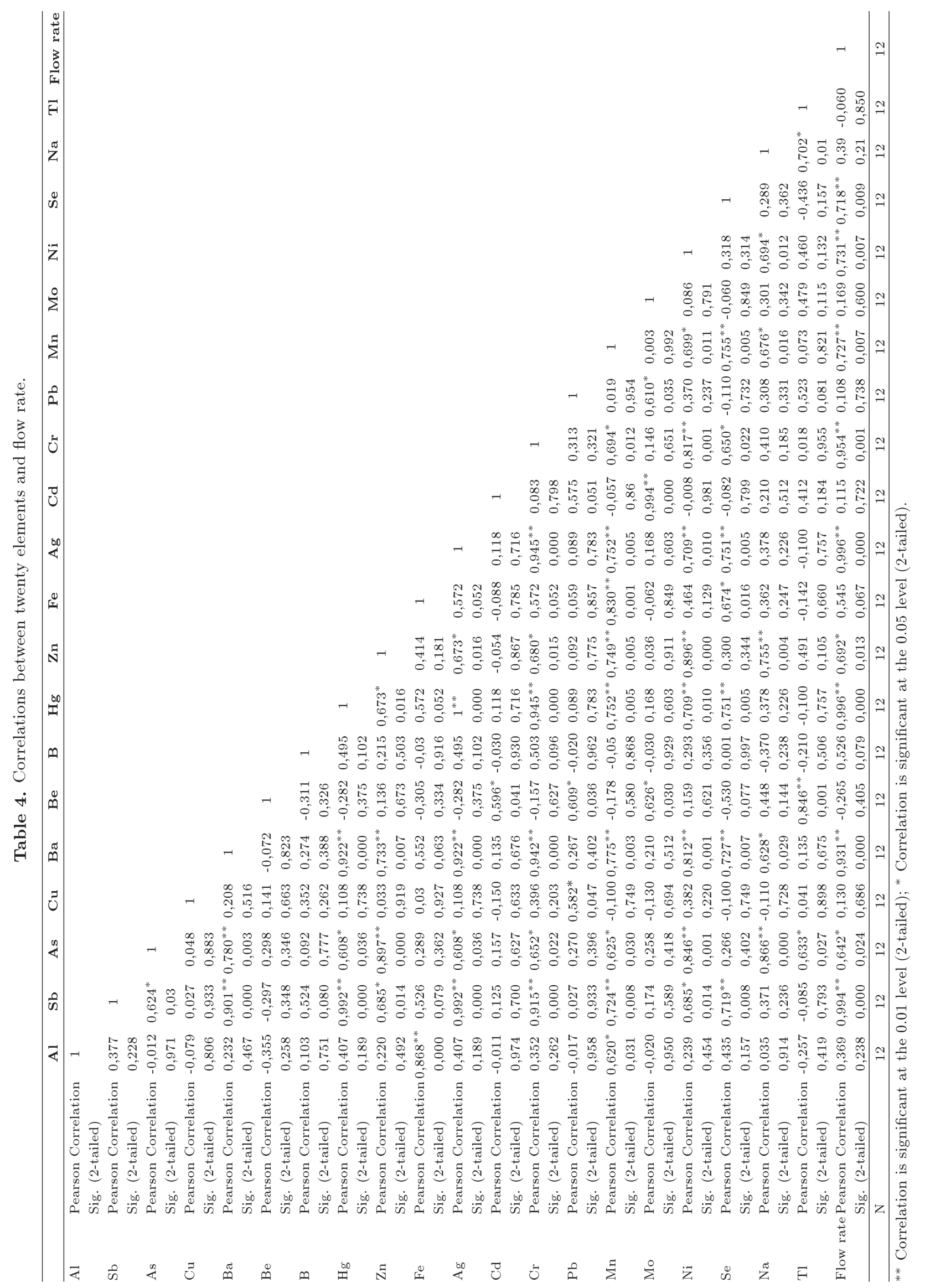




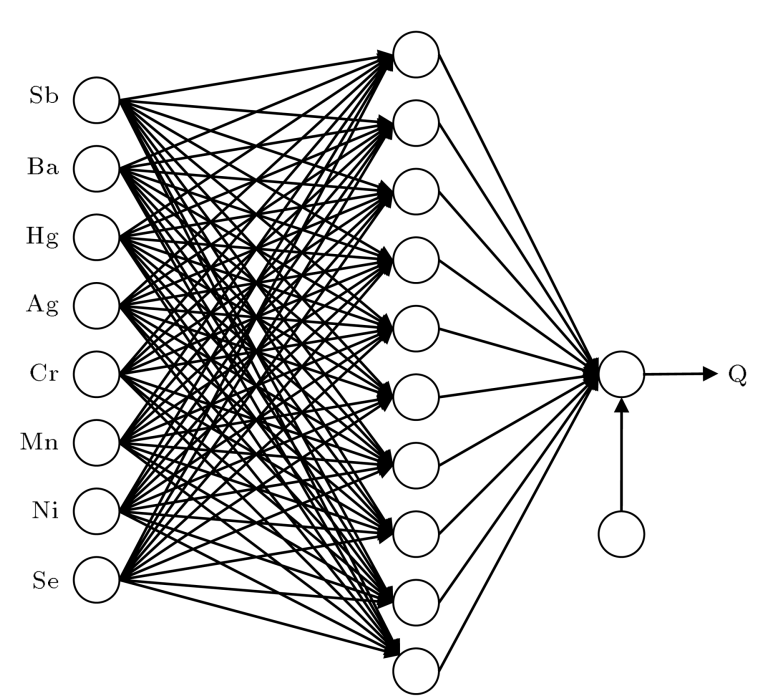

Figure 2. The architecture and weights of proposed model.

neurons are:

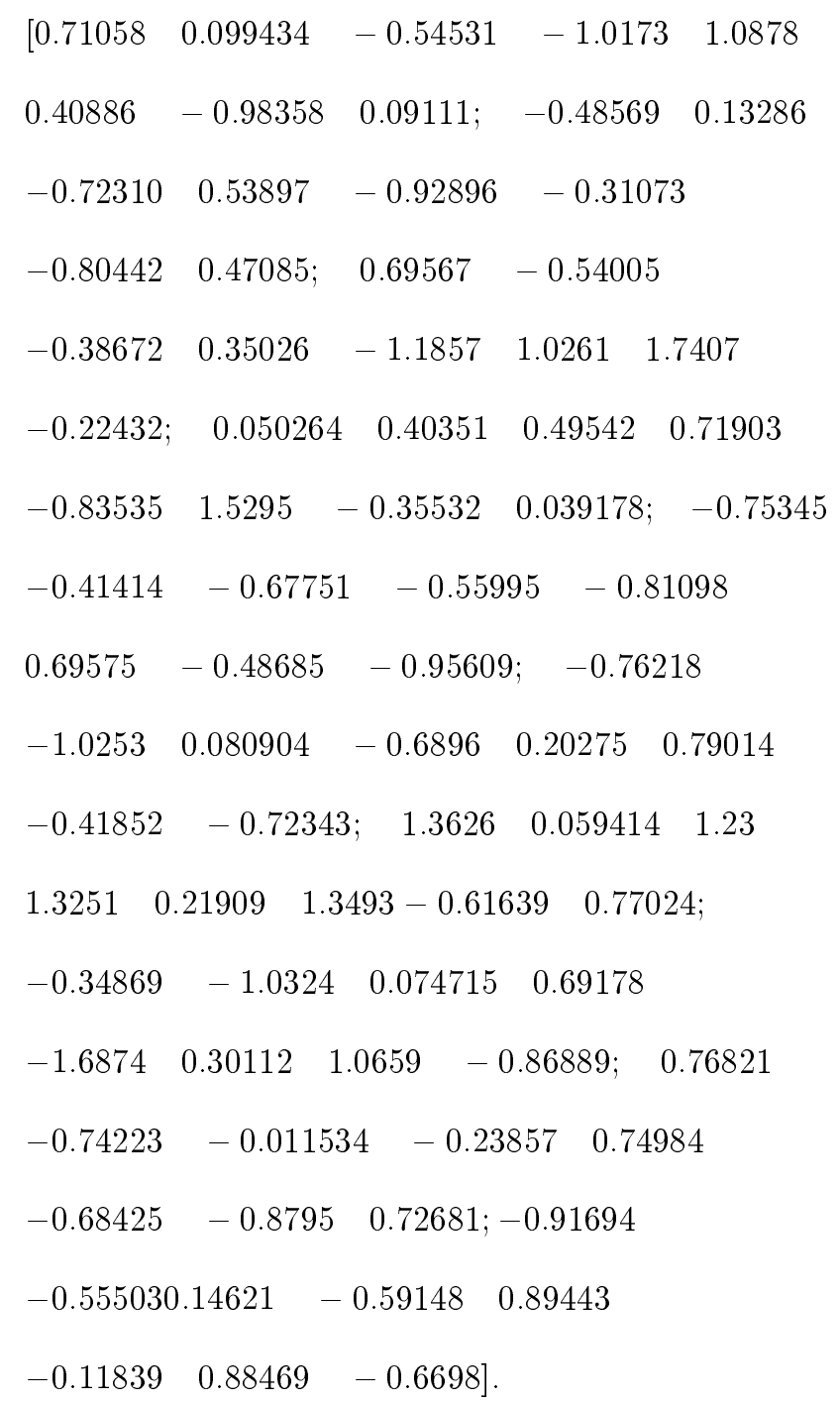

Weights from the hidden layer to the output layer are:

$$
\left.\begin{array}{llllll}
0.58584 & -0.30292 & 1.4812 & 0.64869 & -0.72639 \\
0.28489 & -1.3803 & 1.6485 & 0.8801 & -1.1253
\end{array}\right]
$$

The bias values from the input layer to the hidden layer are:

$$
\begin{aligned}
& {[-1.7472 ; \quad-2.0164 ; \quad-1.0633 ; \quad-0.79299 ; \quad 0.44741 ;} \\
& -0.17386 ; \quad 0.80567 ; \quad-1.3564 ; 1.5362 ;-1.9836]
\end{aligned}
$$

and the bias value from the hidden layer to output layer is:

$$
[0.50037]
$$

Therefore, an effective bias, weights, and the number of hidden neurons are determined by trials for the hidden layers, since there is no rule to determine it. Lastly, real data are compared with the predicted and actual data.

\section{Results}

Determination of the pollution control flow of each reservoir needs to be in values of river without water pollution of inflows released from reservoir to river in events such as drought management in a multi-reservoir system. In this study, first, the correlation analysis is made to investigate the gravity influence of elements which causes water pollution and disturbs water quality on flow rate. When the data obtained from correlation analysis are investigated, it is observed that only eight of twenty elements have been the gravity influence on flow rate. Later, ANN models are developed to be used as input data of eight pollution elements and also as output data of the flow rate against these elements. In ANN models, training and testing are performed by the measured data of the Lower Sakarya River. At the same time, the regression equation is obtained by regression analysis applied to these eight data and flow rate.

The pollution control flow causing the water pollution is obtained by data and constraints presented for the standards of water quality such as TSI, EC, and WHO in the developed ANN models and the regression equation for the Lower Sakarya River. Table 5 shows the comparison of the results obtained from ANN models and regression analysis. With ANN model of calculation, it has ended up with a deviation of $0.97 \%$ from real data. In order to reach this result, several trials have been made by changing weights and the number of hidden neurons. It can be seen from the table that the quality of this method is somehow high, and predicting the cost with this method is preferable. It can be seen that the results of the prediction of the data are comparable. The average deviation produced 
Table 5. Comparison of the results obtained from ANN models and regression analysis.

\begin{tabular}{ccccccccccc}
\hline $\begin{array}{c}\text { Actual } \\
\text { data }\end{array}$ & Reg & Dev\% & $\begin{array}{c}\text { ANN } \\
(\mathbf{1})\end{array}$ & Dev\% & $\begin{array}{c}\text { ANN } \\
\mathbf{( 2 )}\end{array}$ & Dev\% & $\begin{array}{c}\text { ANN } \\
\mathbf{( 3 )}\end{array}$ & $\begin{array}{c}\text { Dev\% } \\
\text { ANN }\end{array}$ & $\begin{array}{c}\text { AN) } \\
\text { Dev\% }\end{array}$ \\
\hline 76,500 & 76,224 & 0,004 & 76,471 & 0,000 & 76,498 & 0,000 & 81,386 & 0,064 & 77,143 & 0,008 \\
127,000 & 111,277 & 0,124 & 126,562 & 0,003 & 125,956 & 0,008 & 126,367 & 0,005 & 125,891 & 0,009 \\
108,000 & 108,935 & 0,009 & 107,991 & 0,000 & 108,006 & 0,000 & 126,989 & 0,176 & 108,494 & 0,005 \\
48,700 & 48,285 & 0,009 & 48,720 & 0,000 & 48,722 & 0,000 & 18,800 & 0,614 & 48,787 & 0,002 \\
23,800 & 6,132 & 0,742 & 23,752 & 0,002 & 27,055 & 0,137 & 18,738 & 0,213 & 22,544 & 0,053 \\
23,800 & 37,840 & 0,590 & 23,993 & 0,008 & 27,399 & 0,151 & 48,724 & 1,047 & 24,911 & 0,047 \\
38,800 & 27,530 & 0,290 & 38,534 & 0,007 & 27,061 & 0,303 & 42,103 & 0,085 & 39,392 & 0,015 \\
18,700 & 24,011 & 0,284 & 20,325 & 0,087 & 27,201 & 0,455 & 18,707 & 0,000 & 19,564 & 0,046 \\
32,100 & 48,011 & 0,496 & 32,304 & 0,006 & 28,409 & 0,115 & 35,684 & 0,112 & 30,528 & 0,049 \\
69,600 & 67,369 & 0,032 & 69,590 & 0,000 & 69,605 & 0,000 & 70,942 & 0,019 & 69,702 & 0,001 \\
55,300 & 79,971 & 0,446 & 55,237 & 0,001 & 55,433 & 0,002 & 124,876 & 1,258 & 55,619 & 0,006 \\
96,700 & 78,386 & 0,189 & 96,697 & 0,000 & 96,695 & 0,000 & 83,669 & 0,135 & 96,515 & 0,002 \\
MAPE & & 0,268 & & 0,010 & & 0,098 & & 0,311 & & 0,020 \\
\hline
\end{tabular}

Table 6. Values of the pollution control flow for the standards $\left(\mathrm{m}^{3} / \mathrm{s}\right)$.

\begin{tabular}{cccc}
\hline \multirow{4}{*}{ Models } & $\begin{array}{c}\text { Surkish Standards } \\
\text { Institute } \\
\text { (TSE-2005) }\end{array}$ & $\begin{array}{c}\text { European } \\
\text { Commission } \\
\text { (EC-1998) }\end{array}$ & $\begin{array}{c}\text { The World Health } \\
\text { Organization } \\
\text { (WHO-2003) }\end{array}$ \\
\hline Regression analysis & 72.949 & 72.949 & 153.270 \\
ANN1 model & 90.234 & 90.234 & 126.994 \\
\hline
\end{tabular}

by regression is $26.79 \%$. The difference is higher than that of ANN models. The worst result is obtained by regression analysis.

The resulted data range from $6.132 \mathrm{~m}^{3} / \mathrm{sec}$ to $126.562 \mathrm{~m}^{3} / \mathrm{sec}$ and the average flow is approximately $59.756 \mathrm{~m}^{3} / \mathrm{sec}$. As can be seen from Table 5 , ANN1 model gives a better result for forecasting flow. There an is approx. $19 \%$ difference between two methods. Flow values of the pollution control for TSI, EC, and WHO are given in Table 6 by ANN1 model and regression analysis.

When data given in Table 6 are investigated, it is observed that data and constraints presented for the standards of the water quality, such as TSI and EC, were the same data obtained by ANN1 model and regression equation. Therefore, data and constraints of both standards are formed due to having very close values with each other. As the data and constraints of WHO are more prohibitive than other standards, the values of the pollution control flow appear as bigger than the values obtained from other standards. In addition, when data given in Table 2 and Table 6 are investigated, it is seen that the constraint of the pollution control flow in river is provided for three months according to TSI and EC, but water pollution is continued in the other months.

\section{Conclusions}

Determination of the pollution control flows of each reservoir needs to be in values of river without water pollution of inflows released from reservoir to river in events such as drought management in a multi-reservoir system. Therefore, the correlation analysis was made to investigate the gravity influence of elements which cause water pollution on flow rate in the river. The data obtained from correlation analysis were used in ANN model and the regression analysis. The pollution control flow was determined by data, and constraints were presented for the standards of the water quality such as TSI, EC, and WHO. The regression analysis and ANN model were developed for the Lower Sakarya River. It was observed that ANN model is $19 \%$ better than regression analysis when obtained results are compared with regard to these standards. It is seen that pollution control flow is raised when the constraints about water quality are increased. In addition, the constraint of the pollution control flow in river is provided for three months according to TSI and EC, but water pollution is continued in the other months. Therefore, water structures need to prevent sediment transport urgently.

In further studies, the pollution control flows may 
be determined for those regions by similar analyses in the Upper and Middle Sakarya River. Thus, it can be said that its pollution control flows for drought control and management in a multi-reservoir system on the Sakarya River will be carried out more effectively and successively.

\section{Acknowledgements}

Temel Temiz, Onur Ozturk, and Burcu Ozcan helped tremendously in developing the idea of this work and provided valuable discussions and guidance.

\section{References}

1. Dundar, M.S. "Determination of water and sediment quality of the lower sakarya river", Report: 106Y037, The Scientific and Technological Research Council of Turkey (2008).

2. Ham, J., Yoon, C.G., Kim, H.J. and Kim, H.C. "Modeling the effects of constructed wetland on nonpoint source pollution control and reservoir water quality improvement", Journal of Environmental Sciences, 22(6), pp. 834-839 (2010).

3. Misaghi, F. and Mohammadi, K. "Estimating water quality changes in the Zayandeh-Rud River using artificial neural network model", The Canadian Society for Engineering in Agricultural Food and Biological Systems, 115(3), pp. 1-11 (2003).

4. Sengorur, B., Dogan, E., Koklu, R. and Samandar, A. "Dissolved oxygen estimation using artificial neural network for water quality control", Fresenius Environ. Bull, 15, pp. 1064-1067 (2006).

5. Hsieh, C.D. and Yang, W.F. "Optimal nonpoint source pollution control strategies for a reservoir watershed in Taiwan", Journal of Environmental Management, 85, pp. 908-917 (2007).
6. Dogan, E., Sengorur, B. and Koklu, R. "Modeling biological oxygen demand of the Melen River in Turkey using an artificial neural network technique", Journal of Environmental Management, 90, pp. 1229-1235 (2009).

7. Mirzaee, A.R. "Effect of drought on river pollution with artificial neural network", Open Access Scientific Reports, 1(10), pp. 1-3 (2012).

8. Mohsenifar, K., Pazira, E., Panahpour, E. and Beni, Z.H.M. "Effect of drought on pollution of LENJ Station of Zayandeh Rood River by artificial neural network and effect of salinity in this region agriculture", International Journal of Agronomy and Plant Production, 1(2), pp. 55-60 (2010).

9. Momblanch, A., Arquiola, J.P., Munné, A., Manzano, A., Arnau, J. and Andreu, J. "Managing water quality under drought conditions in the Llobregat River Basin", Science of the Total Environment, 503-504, pp. 300-318 (2015).

10. Isik, S., Dogan, E., Kalin, L., Sasal, M. and Agiralioglu, N. "Effects of anthropogenic activities on the lower Sakarya River", CATENA-Journal of Soil Science-Hydrology-Geomorphology Focusing on Genecology and Landscape Evolution, 75, pp. 172-181 (2008).

\section{Biography}

Mücahit Opan was born in 1974 in Sivas of Turkey. He received his BS degree from Selçuk University in Konya, his MS degree from Yıldız Technical University in Istanbul, and his PhD from Kocaeli University, respectively, in Civil Engineering. Currently, he is working as an Associate Professor in the Department of Civil Engineering in Kocaeli University. 